消化器癌に対する経内視鏡的レーザー治療の試み

\title{
Endoscopic laser Therapy for G.I. Tract Cancer
}

栅山年和，木村 明，永田 徹，羽生信義，吉田 涊

瀨川 豊, 柳沢 暁, 高野 哲, 曾爾一頙, *長尾房大

\author{
T. SAKUYAMA ,A. KIMURA ,T. NAGATA, N. HANYU, S. YOSHIDA, \\ Y. SEGAWA, S. YANAGI SAWA, S. TAKANO,K. SOJI ${ }^{*}$ F. NAGAO \\ 富士市立中央病院外科， *東京慈患会医科大学第 2 外科
}

6 Cases of various G. I.tract cancer have been treated with laser irradiation by using an endoscopic Nd-YAG laser equipment. A total of 6 cases, 3 with gastric cancer, 2 with esophageal cancer, one with cancer of bile duct were treated Post theraptic evaluation was assessed by subjective symptoms or endoscopic findings including biopsy. About 2 cases with one esophageal and the cancer of bile duct, the therapy was insufficient. But in all the remaining cases, the therapy for the reduction of tumor mass and improving general status judged to be effective. In these cases, our technique is mainly used as palliative procedure to reduct tumor mass. But the possibility still remains for its application by the improvement of the technique and the equipment.

最近, 当病院に心ける消化器癌 6 例飞つn て，経内視箁下レーザー治療を試みたので， 報告士る。

対象己方法：表1亿表すよう飞症例は6 例 で, 胃樒 3 例, 全道癌 2 例, 胆管瘦 1 例です る。Nd-YAGレーザーの熱エネルキー交

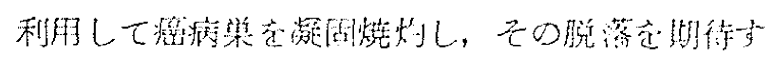

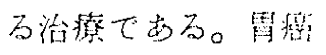
企道㺕の 5 例忖，上 部消化器内視鏡下化 行的, 胆管情火力n て隹, PTCS 利用 

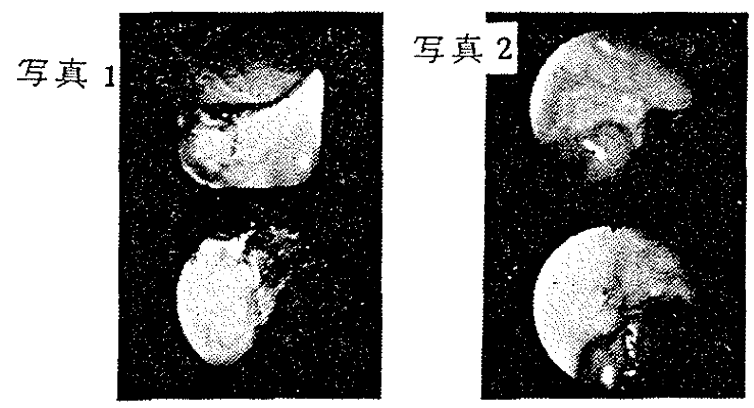

写真
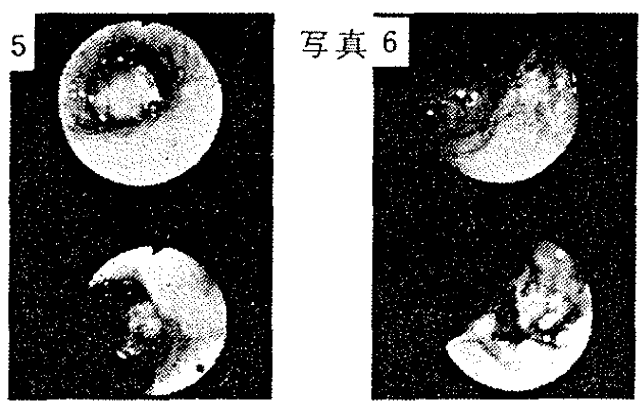

L衣。

次に個々の症例を示寸。症例I；83才，男珄，

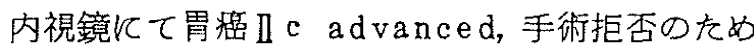
レーザー治療を 2 回行った。写真(1)上段は，治療 前で，胃角小䄳側飞陷凹性病变がみられる。写真 (1)下段は，治療中で一部レーザーにより烧灼され ている。写真(2)上段は，治療 1 週後で、レーザー 溃湯が認められる。写真(2)下段は，治療 3 週後に て, 溃船の樎小を認め, 生検儿ては, negative であった。症例川；68才，男性，食道矮にて，前 回手術拒否, 放射線療法 2 クールにて著效。1 年 半後再発，通過障害あり，レーザー治療を施行し た。写真(3)上段は，治療前にて，右側烽起性病 変が認められる。写真(3)下段は，治療 1 回後，レ 一ザー焼灼に上る跡が認められる。写真(4)上段は,

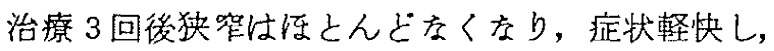
食事摄取可能となり，生検にてる，negative であった。写真(4下段では，6ケ月後，再度腫瘤 增大し, 手術施行, 摘出標本ては，約 $35 \mathrm{~cm}$ 長の main tumor $<$ skip lesion tumor lesionにつんては, submucosaまての浸閏で あった。症例川；66才，男性，残胃癌，食道浸潤 通過障害強く， C T上にて腫捥は，胸部大動脈を まき込んており，手術不能と判断，腸提造設後レ
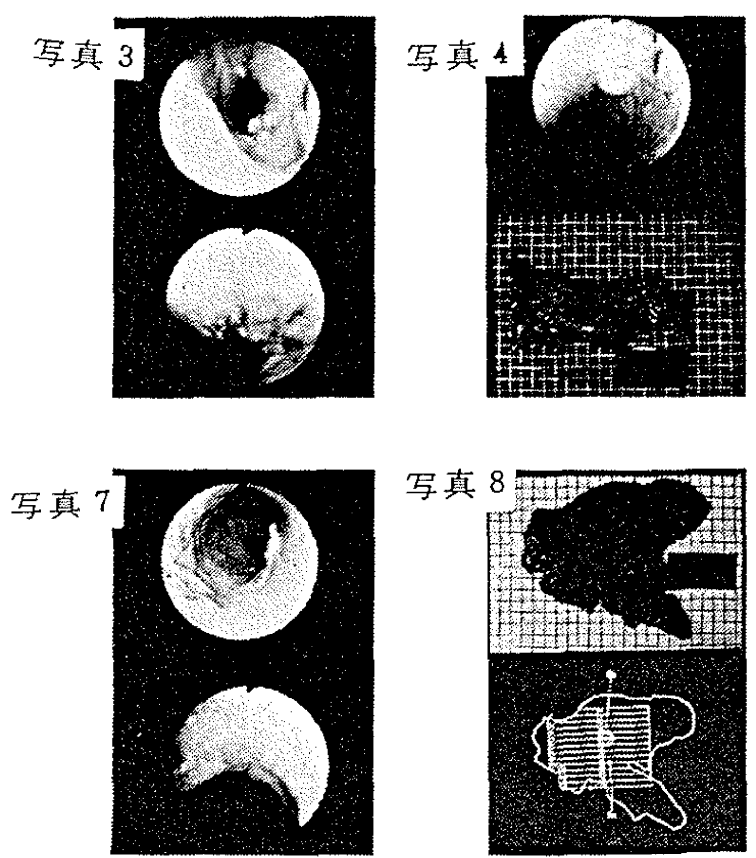

ーザー治療を施行した。写真(5)上段は，施行前の 内視鏡で，内腔を臣閏塞するtumor mass が 認められた。写真(5)下段壮，治療 3 回後の所見て， 狭窄は改善し，全强まで摄取可能となり約4 ケ月 間，経口摂取可能であっ方。症例 V; 54才, 男性. 食道静脈瘤破裂に上る出血にて緊急内視鏡にて硬 化療法施行，乙の時胃角部の】cあり，その時点 では手術不能と判断し，レーザー治療 2 回施行し た。写真(6)下段は, 治療前の胃角部の11 cて, 写 写(6)下段は，治療中，一部レーザーによる枆灼 が認好られる。写真(7)上段恃, 治㞠後レーザー潰 嚓に白苔が認的られる。その後 follow up中生 検 negaive であったか，6ケ月後の内視鏡所見 では，写真(7)の下段のじとく，胃角部に】a 様の

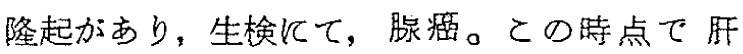
機能, 腹水の controlができ, 切除可能之判断 し手術施行，写真(8)に示す如〈，照射部位壮約 4 $\mathrm{mm}=\frac{\mathrm{E}}{2}$ 】 $\mathrm{a}$ 縮小した。また病理所見では, 随伴す るI bが見られる多発胃瘦であった。結語; 症例 は，すべて姑息的治療であったが，レーザー治療 により，早期に症状の改善ができ，また tumor reductionとしてす，再発進行富化有効である。 胆道采の悪性腫汤に対して子，PTCSt利用して の治療がでをるると考える。治療法の改善、工夫に より、経内視鏡的レーザー治療の適応をより桩大できる。 